\title{
Mengenal Pemikiran Al-Mubarrid dan Kontribusinya terhadap Perkembangan Ilmu Balāghah
}

\author{
Dasep Bayu Ahyar \\ Magister Pendidikan Bahasa Arab \\ Universitas Islam Negeri (UIN) Syarif Hidayatullah Jakarta \\ Email:dasepbayuahyar93@gmail.com
}

\begin{abstract}
Through this article the author introduces the beginnings of al-Balaghah alMubarrid's thoughts and contributions to the world of Arabic literature. Balaghah is a discipline of Arabic language that continues to experience development and renewal among the scholars, with the birth of balaghah we can understand and know how to communicate a meaning to the recipient of the message with beautiful language, on target, effective, and in accordance with the situation and conditions (al-Muqtadhol Hal). The study of balaghah has been carried out by many scholars in producing their best work. In this article the author will review Mubarrid-thinkers and their contributions to the development of Baläghah. This article uses the library research writing methodology (library research) using descriptive analysis methods, namely by collecting data, compiling or clarifying, compiling and interpreting it. Abu al-Abbas Muhammad ibn Yazid has contributed his thoughts in the treasury and has many of his works, and the most menumental work in the study of languages, especially in Balaghah studies is the book of alKâmil fi al-Lughah wa al-Adab. Where this book contains discussions about linguistics, Islamic culture, literature, history, and grammatical. The Arabic literature contained in this book is not only in the form of prose and poetry, but also proverbs, aphorisms, poems (poems) and weighted (quality) sermons.
\end{abstract}

Keywords: Al-Mubarrid, Pemikiran, Al-Baläghah

\section{ملخص}

هدف هذا البحث لمعرفة ببد اية أفكار المبرد عن البلاغة وإسهاماته في عالم الأدب العربي. البلاغة من

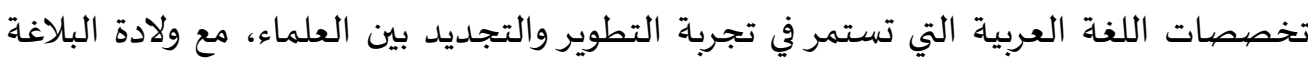
يمكننا أن نفهم ونعرف كيفية إيصال معنى إلى مستلم الرسالة بلغة جميلة، مباشرة على الهدف، فعالة، ووفقًا للموقف و الشروط (مقتضى الحال). تم إجراء دراسة البلاغة من قبل العديد من

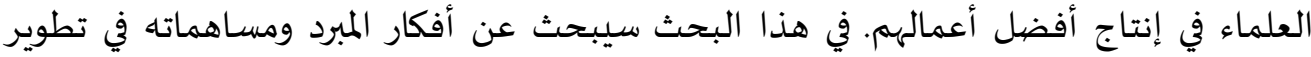

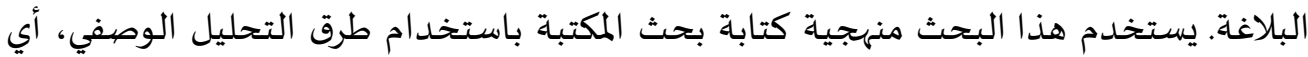

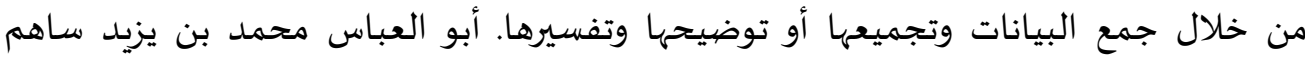




$$
\begin{aligned}
& \text { بأفكاره في الخزينة وله العديد من أعماله، وأهم أعماله في دراسة اللغات خاصة في دراسات }
\end{aligned}
$$

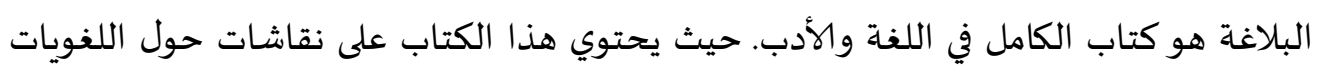

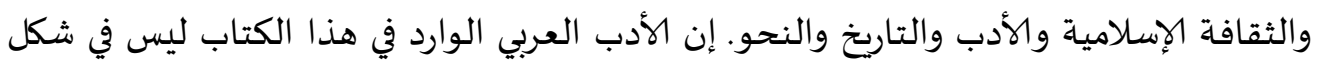

$$
\begin{aligned}
& \text { نثر وشعر حسب، بل هو يضمن أمثال وأشعار بحرية (قصيدات) وخطب (جودة). } \\
& \text { الكلمات الرئيسية: المبرد؛ الأفكار؛ البلاغة }
\end{aligned}
$$

\begin{abstract}
Abstrak
Artikel ini bertujuan untuk memperkenalkan awal tentang pemikiranpemikiran al-Balaghah al-Mubarrid dan kontribusinya bagi dunia sastra Arab. Ilmu Balaghah merupakan sebuah disiplin ilmu bahasa Arab yang terus mengalami perkembangan dan pembaharuan dikalangan para ulama, dengan lahirnya ilmu balāghah kita bisa memahamidan mengetahui bagaimana cara untuk mengomunikasikan sebuah makna kepada penerima pesan dengan bahasa yang indah, tepat sasaran, efektif, dan sesuai dengan situasi dan kondisi (al-Muqtadhol Hal). Kajian ilmu balaghah telah banyak dilakukan oleh para ulama dalam menghasilkan karya terbaiknya. Dalam Artikel ini penulis akan membahas tentang pemikiran-pemikiran al-Mubarrid dan kontribusinya terhadap perkembangan ilmu Balāghah. Artikel ini menggunakan metodologi penulisan penelitian kepustakaan (library research) dengan menggunakan metode analisis deskriptif, yaitu dengan jalan mengumpulkan data, menyusun atau mengklarifikasi, menyusun dan menginterpretasinya. Abu al-'Abbas Muhammad ibn Yazid telah menyumbangkan pemikiran-pemikirannya dalam khazanah kebahasaraban dan telah banyak karya-karya beliau, dan karya yang paling menumental dalam kajian kebahasaaraban khususnya pada kajian Balaghah adalah kitab al-Kâmil fi al-Lughah wa al-Adab. Dimana kitab ini memuat pembahasan tentang linguistik, kebudayaan Islam, sastra, sejarah, dan gramatikal. Sastra Arab yang dimuat dalam buku ini tidak hanya berupa prosa dan puisi, melainkan juga pribahasa, kata-kata mutiara, syair-syair (puisi-puisi) dan khutbah-khutbah berbobot (bermutu).
\end{abstract}

\title{
Kata Kunci: Al-Mubarrid, Pemikiran, Al-Balāghah
}

\section{Pendahuluan}

Balāghah pada zaman Jahiliyah (pra islam)pada dasarnya telah menjadisebuah ungkapan yang sudah terbiasa digunakan oleh kalangan kabilah-kabilah arab dalam kehidupan sehari-hari,dimana perkataan-perkataan yang bernilai Balāghah menjadi suatu komunikasi dalam kehidupan mereka. Penduduk Arab masa Jahiliyah sebelum Al-Qurān Allah turunkan, bahwa orang-orang arab Jahiliyah telah masyhur sebagai ahli di bidang sastra. Maka tidak heran pada masa itu terdapatpasar Ukaz dengan hadirnya pasar ini maka kontes-kontes atau perlombaan-perlombaan pembacaan syair atau puisi di gelar.

Sejarah telah mencatat bahwa bangsa Arab Jahiliyah telah mencapai tingkatan yang tinggi dalam balāghah dan diksi. Mereka sangat bangga, lalu mengaplikasikannya ke dalam 
bentuk kalam seni prosa dan puisi. Sederet nama penyair terkenal semisal Zuhair Ibn Abi Salma, Amru Ibnu Kultsum, Tarfah, Al Khansa, Umru' al Qais, al Nabighah al Dubyani, Haris bin hillizah al Yasykary, Lubaid bin Rabi'ah dan lainnya1, di mana mereka mengekspresikannya karya sastranya di pasar-pasar, seperti Ukaz(antara Mekah dan Thaif), Pasar Majnah (antara Mekah dan Zahran) dan pasar Dul Majaz (antara Mekah dan Mina).Diantara karya-karya mereka yang berkualitas tinggi tersebut digantung di Ka'bah, para linguis arab menamakan karya-karya mereka dengan "al Mua'alliqat" meskipun sebagian lain tidak sependapat karena Ka'bah mengalami banjir besar yang dapat menghancurkan karya-karya tersebut (Thabrani, 2018). Balāghah dari masa jahiliyah hingga masa sekarang terus mengalami pertumbuhan dan perkembangan. Pada masa sekarang yang dijadikan objek dari kajian balāghah ini bukan hanya sebatas syair, prosa akan tetapi setelah balāghah menjadi sebuah disiplin ilmu objek kajian Balāghah berkembang kepada kajian ayat-ayat Al-Qurān yang secara terus menerus di kaji oleh para ulama.

Sebagaimana Al-Qurān merupakan kitab sastra terbesar sepanjang sejarah bumi. Keindahan al-Qurān mencerai-beraikan semua norma keunggulan sastra yang pernah dikenal bangsa Arab. Setiap ayat al-Qur'an memenuhi semua norma keindahan sastra yang mereka kenal, bahkan mengunggulinya. Oleh karena itu, al-Qurān mampu memperdaya lawan-lawannya begitu dipresentasikan. Bacaannya sangat mempesona dan mengangkat mereka ke puncak tertinggi kenikmatan sastra. Itulah mengapa bangsa Arab menganggap al-Qurān sebagai mukjizat, sehingga mereka mengakui asal-usul kelahirannya, dan tunduk kepada perintahnya. Bangsa Arab sangat menikmati keindahan ayat demi ayat dalam alQurān, mereka seakan hanyut dengan keindahan sastranya. Sehingga, merekapun malu membuat karya sastra seperti yang selama ini mereka bangga-banggakan. Dan kini karya yang mereka buat terpengaruh dengan al-Qur'an, baik itu dari segi makna, lafadh, susunan dan gaya bahasa (Umroh, $\mathrm{tt}$ ).

Al-Qurān selalu menampakansuatu keajaibanyang dahsyat saat di kaji. Semakin banyak yang mengkaji isi al-Qur'an, maka semakin nampak kemukjizatan Al-Qurān. Kemukjizatan Al-Qurān akan timbul dari berbagai aspek baik dari segi bahasa, kata, bunyi dan masih banyak lagi yang membedakan antara kitab lainnya yang di turunkan Allah kepada para utusannya. Dari kitab Al-Qurān inilah muncul berbagai karya ulama yang mengkaji kemukjizatannya sehingga al-Qurān mendapat perhatian bukan hanya dari kalangan ulama islam itu sendiri melainkandarikalangan pemikir linguistik barat.

Al-Qur'an merupakan media yang efektif untuk dinikmati dan dihayati, karena di dalamnya mengandung nilai-nilai sastra yang sangat tinggi dengan keindahan bahasa dan pesona yang dimilikinya. Sehingga banyak sahabat yang meneteskan air mata karenatakjub dan terpukau dengan keindahan untaian kata dan gaya bahasa al-Qurān. Itulah gaya kalam Allah yang mengalahkan semua ahli balaghah (keindahan bahasa) dan sastra (Istianah, 2014).

Keindahan dan keagungan Al-Qurān yang dimilikinya tentu menjadi suatu keajaiban dan keunikan daripada kitab lainnya. Al-Qurān telah mampu mengalahkan dan membuat 
takjub para penyair orang-orang jahiliyah sehingga Allah Swt menantang mereka agar membuat suatu pemislaan (contoh) seperti Al-Qurān akan tetapi mereka tidak mampu menjawab tantangan itu.Hal ini termaktub dan Allah abadikan dalam firman-Nya (Qs. AlBaqarah, 23-24),

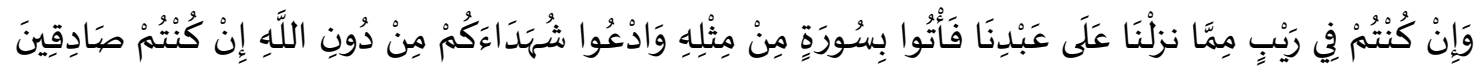

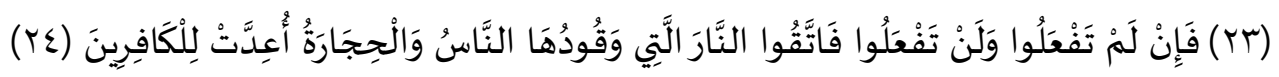

"Dan jika kamu (tetap) dalam keraguan tentang Al Quran yang Kami wahyukan kepada hamba Kami (Muhammad), buatlah satu surat (saja) yang semisal Al Quran itu dan ajaklah penolong-penolongmu selain Allah, jika kamu orang-orang yang benar. Maka jika kamu tidak dapat membuat (nya), dan pasti kamu tidak akan dapat membuat(nya), peliharalah dirimu dari neraka yang bahan bakarnya manusia dan batu, yang disediakan bagi orang-orang kafir."

Secara jelas Al-Qurān telah mampu membuktikan suatu peradaban dan tradisi menulis yang sangat tinggi karena dari Al-Qurān ini telah banyak melahirkan karya-karya dan produk para ulama. Semua ini muncul karena ada sebuah kebenaran dan keyakinan bahwa Al-Qurān adalah firman Allah (kalamullah) dan sekaligus kitab suci pedoman umat islam (Abdullah, 2014). Sebagian kecil ulama menganggap orang yang mengabdikan dirinya untuk bahasa Arab dan mengarang buku-buku tentang bahasa Arab dipandang pula bentuk pengabdian kepada Allāh dan al-Qur'an. maka hal tersebut juga dianggap sebagai pengabdian terhadap al-Qurān (Dewi, 2016).

Ulama terdahulu telah banyak memberikan kontribusi pemikirannya terhadap khazanah keilmuan islam, dan salah satu ulama yang memberikan dan mendedikasikkan dirinya untuk menulis sebuah karya ilmu dalam bidang kajian Balāghah adalah AlMubarrid. Tulisan ini akan mengkaji pemikiran-pemikiran Al-Mubarrid dan kontribusinya terhadap kajian ilmu Balāghah.

\section{Metodologi Penulisan}

Penelitian ini adalah penelitian kepustakaan (library research) dengan menggunakan metode analisis deskriptif, yaitu dengan jalan mengumpulkan data, menyusun atau mengklarifikasi, menyusun dan menginterpretasinya (Surakhmad, 1980). Metode deskriptif yang dipilih karenapenelitian yang dilakukan bertujuan untuk menggambarkan dengan jelas tentang objek yang diteliti secara alamiah (Djajasudarma 1993:). Sementara itu, kajian deskriptif menurut Chaer (2007:9) biasanya dilakukan terhadap struktur internal bahasa, yaitu struktur bunyi (fonologi), struktur kata (morfologi), srtuktur kalimat (sintaksis), struktur wacana, dan struktur semantik. Kajian deskriptif ini dilakukan dengan mula-mula mengumpulkan data, mengklasifikasi data, lalu merumuskan kaedah-kaedah terhadap keteraturan yang terdapat pada keteraturan data itu khususnya kajian morfsintaksis. 


\section{Pembahasan dan Hasil}

\section{Biografi Intelektual Al-Mubarrid}

Al-Mubarrid (المبرّد) bernama lengkap Abu al-'Abbas Muhammad ibn Yazid ibn 'Abdillah al-Azdi al-Tsumali, lahir di Bashrah pada 210 H/826 M. Ada yang berpendapat bahwa ia lahir pada 207 atau 195 H, dan meninggal di Baghdad pada 285H/898M. Sebutan "al-Mubarrid" (yang menyejukkan, mendinginkan) diberikan oleh gurunya al-Mazini (w. 247 H), penulis Kitâb al-Tashrîf, karena kemampuannya memberikan jawaban yang cerdas dengan argumentasi mendasar, kokoh dan detail ketika ditanya gurunya mengenai "ل」". Namun, oleh kalangan pengikut aliran Kufah, sebutan itu "diplesetkan" menjadi "alMubarrad" (yang dibekukan), sebagai ejekan terhadapnya. Ia termasuk salah seorang tokoh generasi atau angkatan ketujuh (ada yang berpendapat kedelapan) aliran Bashrah, seangkatan dengan Abu al-'Ala' al-Bahili (w. 257 H) (https://fitk.uinjkt.ac.id/).

Ia belajar ilmu Sharf (morfologi) kepada Abu Utsman al-Mazini, dan ilmu nahwu kepada Abu 'Umar al-Jarami (w. 225 H), yang juga beraliran Bashrah. Dari al-Jarami, ia membaca al-Kitâb karya Sibawaih. Kecerdasan dan kemahirannya berargumentasi dalam bidang nahwu membuatnya cepat "naik daun" (populer), sehingga Khalifah al-Mutawakkil dan menterinya, al-Fath ibn Khaqan mengundangnya ke Samarra pada $246 \mathrm{H}$ untuk dimintai fatwa yang benar mengenai beberapa persoalan nahwu. Tidak diperoleh informasi mengenai detail persoalan yang difatwakan saat itu, namun kedekatannya dengan istana kerajaan membuatnya sering mendapat hadiah dari al-Mutawakkil dan menterinya tersebut.

Ia juga pernah memberikan kuliah tentang bahasa dan Nahwu di hadapan para mahasiswa di Baghdad, dan terlibat beberapa kali munâzharah (perdebatan) dengan Tsalab (w. $291 \mathrm{H}$ ), salah seorang tokoh alirah Kufah yang hidup pada masanya. Dalam berbagai perdebatan itu,diperoleh informasi bahwa al-Mubarrid selalu dapat mematahkan pendapat Tsa'lab dengan argumentasi yang memukau dan logis (https://fitk.uinjkt.ac.id/).

\section{Guru-guru Al-Mubarrid}

Al-Mubarrid didalam mendalami ilmu kebahasaaraban telah banyak guru-guru yang ia jumpaipada masanya dan belajar banyak darinya, diantara guru-gurunya yaitu (atTawab, $\mathrm{tt}$ ):
a. Al-Jahizh (w $255 \mathrm{H}$ )
b. Al-Jarmi (w 225)
c. Al-Jiyadi (w $249 \mathrm{H}$ )
d. Al-Riyāsyi (w $257 \mathrm{H}$ )
e. Al-Sijistānī (w $255 \mathrm{H}$ )
f. Umārah bin Aqīl bin bilāl bin Jarīr (w 239 H)
g. Al-Māzanī (w 249 H)
h. Al-Mughīrah 


\section{Murid-murid Al-Mubarrid}

Al-Mubarrid merupakan ulama masyhur pada masanya dan ini terbukti yang ditandai dengan banyaknya para ulama Masyhur setelahnyayang berguru kepadanya, dan diantara murid-muridnya yaitu ('Adlimah, $\mathrm{tt}$ ):

a. Az-Zujaj, murid yang paling dekat dan merupakan murid pertamanya di Baghdad

b. Ash-Shuli

c. Nifthawaih

d. Abu 'Ali ath-Thumari

e. Ibnu as-Siraj

f. Al-Akhfasy al-Ashghar

g. Abu 'Ali Isma'il ash-Shaffar

h. Abu Thayyib al-Wasya`Ab

i. Ibnu al-Mu'taz

j. Abu al-Husain bin al-Jazar

k. Ibnu Darastawaih

l. Abu Ja'far an-Nuhhas

m. Abu Bakar al-Khara`ithi

n. Abu Sahl al-Qaththan

o. Ahmad bin Marwan ad-Dainuri

\section{Karya-karya Al-Mubarrid}

Al-Mubarrid telah mewariskan kepada kita dengan beberapa karya terbaiknya yang begitu sangat penting dalam bidang kebahasaaraban, seperti (Ya'qub, $\mathrm{tt}$ ):

a. Kitāb al-Isytiqāq (kajian fiqh Lughah)

b. Kitāb Ma'ānā Al-Qur'ān

c. Kitāb I'rāb al-Qur'ān

d. Kitāb al-Awsath karya al-Akhfasy

e. Al-Kāmil fi Al-Lughah wa al-Adab (kajian kesusastraan Arab)

f. Al-Muqtadhab (kajian ilmu nahwu)

g. Al-Madkhal Ila Sîbawaih

h. Al-Radd 'ala Sîbawaih atau Masā'il al-Ghalath

i. Syarh Lamiyah al-'Arab

j. Ma Ittafaqa Lafzhuwu wa Ikhtalafa Ma'nahu min al-Qur'an al-Majid

k. Al-Mudzakkar wa al-Mu`annats

Adapun Karya monumentalnya terhadap sastra dan budaya, al-Mubarrid mewariskan karya yaitu al-Kamil fi al-Lughah wa al-Adab. Sesuai dengan judulnya, buku ini memuat kapita selekta tentang linguistik, kebudayaan Islam, sastra, sejarah, dan gramatika. Sastra Arab yang dimuat dalam buku ini tidak hanya berupa prosa dan puisi, melainkan juga pribahasa, kata-kata mutiara, syair-syair (puisi-puisi) dan khutbahkhutbah berbobot (bermutu). Pemikiran otentik linguistik al-Mubarrid dapat direkonstruksi dan dikritisi melalui buku momentalnya tersebut (https://fitk.uinjkt.ac.id). 


\section{Sekilas Sejarah Awal Penulisan Kitab Balāghah Al Mubarrid}

Diantara kitab-kitab Al Mubarrid yang di tulisnya adalah sebuah kitab yang berjudul "Al Balaghah."Kitab ini dianggap sebagai sebuah kontribusi besar dari Al Mubarrid dalam perkembangan ilmu Balaghah. Meskipun kitab ini tergolong sangat ringkas akan tetapi tetap layak untuk dijadikan rujukkan (referensi) (Shomud, 1997). Adapun hal yang mendorong Al Mubarrid dalam menulis kitab ini adalah banyaknya pertanyaan kepadanya dari sebagian penguasa negeri yang menanyakan pendapatnya terkait suatu hal yaitu manakah yang lebih fasih, antara kefasihan sebuah Syi'ir ataukah kefasihan sebuah susunan kalimat biasa dalam bentuk khutbah, prosa dan saja'?. (alMubarrid, tt). Kemudian ia menerangkan bahwasanya istilah Balagah di dalam risalah tersebut digunakan untuk makna khusus yang berkaitan langsung dengan tujuan membandingkan antara dua bentuk kategori tulisan yaitu bentuk tulisan prosa dan puisi (Shomud, 1997).

\section{Pemikiran dan Kontribusi Al-Mubarrid Bagi Ilmu Balāghah}

\section{a. Ilmu Bayan}

Secara etimologi Bayan adalah membuka, menjelaskan, dan tampak. Sedangkan Menurut terminologySyaikh Harish dalam kitabnya "Jauhar Maknun" beliau menuturkan ilmu bayan merupakan dasar-dasar dan kaidah-kaidah untuk mengetahui cara menyampaikan suatu makna dengan beberapa cara yang berbeda-beda beserta sesuainya masing-masing dengan muqtadla al hal (konstektual) (Alaikum, 2015).

Didalam ruang lingkup kajian ilmu bayan, para ahli Balāghah sepakat ada 3 hal, yaitu: (التشبيه) At-Tasybih (المجاز) Al-Majaz dan (الكناية) Al-kinayah.

\section{Al-Tasybih dan Macam-macamnya (التشبيه وأقسامه)}

Tasybih berasal dari perkataan "الشبه "yang berarti sama atau serupa. Ini searti dengan perkatan" مثل"Pada pendapat Ibnu Manzur konsep tasybih memberi arti perumpamaan. Demikian pula pendapat Syauqi Daif yang menjelaskan tasybih adalah menyerupakan sesuatu dan menyamakan sesuatu (Shafiera, 2013). Sedangkan dari segi istilah ahli balaghah, Al-Khatib al-Qazwini memberikan definisi tasybih dalam kitabnya sebagai berikut:"Al-Tasybih ialah menghubungkan satu perkara dengan perkara yang lain dalam sesuatu makna menggunakan partikel yang jelas dan juga tersembunyi bagi sesuatu tujuan yang dimaksudkan oleh seseorang."

Sementara Al-Mubarrid dalam kitabal-Kämil fi al-Lughah wa al-Adabdia memberikan ulasan tentang tasybih. Uraian al-Mubarrid ini dinilai oleh para kritikus sastra kontemporer sebagai sumbangan atau kontribusi yang sangat berarti terhadap perkembangan tasybih dalam diskursus retorika Arab. Ia berpendapat, bahwa tasybih merupakan seni bertutur yang paling sering dipakai dalam ungkapan bahasa Arab. Al Mubarrid dalam membagi bentuk-bentuk tasybih ia mencoba berinteraksi dari dua sudut pandang. 
Pertama, berdasarkan sifat dan faktor-faktor yang memiliki andil dalam memunculkan efek keindahan dan bagiannya dari keindahan. Tasybih ini memiliki keunggulan daripada yang lainnya. Dalam kitabnya al-Kāmil fi al-Lughah wa al-Adabakan banyak kita dapati bentuk-bentuk tasybih berdasarkan sudut pandang ini. Sehingga al Mubarrid berkata dalam ungkapan bahasa arab terkait penggunaan tasybih ada empat macam, yaitu, Al-Mushib, Al-Malih, Al-Mufrith, Al-Maqarrib, dan tasybih Al Ba'id dimana tasybih jenis ini masih membutuhkan penjelasan (Muhammad, 1998). Tampak sekilas bahwa Al Mubarrid terkesan gemar dalam memperbanyak nama-nama daripada bentukbentuk Tasybih. Akan tetapi ia juga terkesan tidak mendetail dalam menetapkan namanama yang berbeda tersebut. Kitatidak menemukan perbedaan-perbedaan yang mendasar diantara bentuk yang banyak tersebut. Yang menjadikan kita akan mengira bahwa penamaan yang terkesan berlebihan tersebut tidak lain hanyalah sekedar memvariasikan nama-nama, dimana nama-nama tersebut tidak menunjukkan akan esensinya masingmasing, dikarenakan tidak ditemukan sama sekali perbedaan diantaranya.

Kedua, Sudut pandang yang kedua ini lebih detail dan lebih banyak didapati kesulitannya daripada yang pertama, hal ini agar pembagian yang terjadi terfokus kepada satu pondasi yang tetap, dan berlandaskan teori dasar dan awal terkait hubungan antara ilmu dan objek pembahasannya serta hubungan ilustrasi dengan setiap misalnya. Tasybih dalam sudut pandang ini dapat dihimpun dalam 4 cakupan, yaitu:

a. Tasybih atau bentuk perumpamaan terkadang sesuai dan tepat sehingga disebut Mushiban

b. Tasybih atau bentuk perumpamaan sifatnya mendekati sehingga disebutMuqariban

c. Tasybih atau bentuk perumpamaan malah jauh sehingga disebut dengan Ba'idan

d. Tasybih atau bentukperumpamaan keluar (tidak sesuai) daripada pengertian Tasybih sehingga disebut Mufrithan.

Al Mubarrid sendiri menganggap sebagian bentuk tasybih yang ditemukan daripada perkataan orang Arab yang masih dalam bentuk prosa.Ia menunjukkan kepada kita dengan berkata: "Tasybih merupakan hal yang banyak ditemukan dalam percakapan manusia. Dan banyak sekali temukan darinya bentuk-bentuk tasybih yang baik. Mereka terkadang menyerupakan mata seorang laki-laki ataupun perempuan dengan mata seekor rusa ataupun seekor sapi peliharaan. Kemudian menyamakan hidung keduanya dengan mata pedang. menyerupakan mulut dengan seekor burung gagak. menyerupakan rambut dengan serentengan buah. Leher dengan sebuah kendi perak. Kemudian menyerupakan betis dengan kerikil. Ini semuanya mengalir begitu saja di lisan mereka (al-Mubarrid, 1998).

Al Mubarrid sendiri banyak menyebutkan bentuk-bentuk tasybih yang beliau cocokkan dengan berbagai bentuk nama yang berbeda, yang mana hal itu menunjukkan akan keindahannya. Akan tetapi pada akhirnya kesemuanya jika ditarik benang merahnya akan kembali kepada 4 macam saja. Al Mubarrid berkata "bentuk perumpamaan orang Arab itu ada empat macam: Tasybih Mufrith, Tasybih Mushib, Tasybih Muqarib, Tasybih 
$B a^{\prime} i d$ dimana untuk macam terakhir butuh kepada penjelasan dalam memahaminya dan dia tidak berdiri sendiri, ia termasuk perkataan yang sukar difahami (al-Mubarrid, 1998) dan bisa kita pastikan bahwa keempat macam bentuk dan sifat tasybih yang disebutkan oleh Al Mubarrid itu mencakup semua bentuk Tasybih yang kita dapatkan didalam ranah ilmu Balagah.

Sebagaimana kita ketahui bahwa Al Mubarrid sendiri sudah memberikan dan mempersembahkan kepada kita sebuah usaha yang nyata, hal itu sangat berguna bagi Ahli Balāgah setelahnya. Usaha nyata tersebut berupa terkumpulnya beragam contoh bentuk puisi baik dari puisi kuno (Syi'ir Jahiliyah), puisi pada masa keislaman (Syi'ir Islami), puisi pada masa pemerintahan Umayyah (Syi'ir umawi) hingga puisi pada masa kerajaan Abbasiyah yang tergolong dekat masa Al Mubarrid, dan semuanya itu mengandung uslub tasybih (al-Mubarrid, 1998).

Pada dasarnya Al Mubarrid bukanlah orang yang pertama yang berbicara mengenai tasybih, namun ulama Balagah sebelumnya jugasudah berbicara mengenai hal itu, semisal Abu Ubaidah, Al Farra', Al Jahizh, dan Ibnu Qutaibah. Akan tetapitidak seorangpun dari mereka yang mencoba membagi tasybih sebagaimana Al Mubarrid jelaskan, dan juga tidak seorang pun dari mereka yang mengkhususkan tasybih di dalam satu Bab, sebagaiman hal itu dilakukan oleh Al Mubarrid (Hamdani, $\mathrm{tt}$ )

Disampingitu pula ada usaha nyata lainnya dari Al Mubarrid berupa terbaginya contoh-contoh yang banyak tentang tasybih kepada bentuk-bentuk yang beragam, hal tersebut berlandaskan kepada Sifat-sifat yang dirasakan dan diketahui sendiri olehnya. Pada hal ini kita mengetahui bahwa ada yang namanya Tasybih Mushib, Tasybih Malih, Tasybih Hasan dan banyak bentuk Tasybih lainnya. Didalam pengambilan contoh-contoh dari tasybih al-Mubarrid juga memberikan penjelasan-penjelasa dan mengambil contoh dari Al-Qur'an beliau mensifati bentuk tasybih yang terdapat di dalam Al Quran sebagaimana Sifat tasybih yang ada di Puisi (Syi'ir).

\section{Al-Kinayah (الكناية) (Metonomia)}

Kني - يكني- كناية Secara bahasa berbentuk mashdar, diambil dari fiil الكناية yang berarti menerangkan sesuatu dengan perkataan yang lain, mengatakan dengan kiasan, atau sindiran.

Sedangkan pengertian الكناية menurut istilah Ilmu balaghah dalam Hasyimi (tt) adalah:

"Suatu kalimat yang diungkapkan dengan maksud bukan makna yang sesungguhnya, akan tetapi tetap diperbolehkan menggunakan makna asli karena tidak ada qarinah (alasan) yang menghalangi penggunaan makna asli tersebut."

Dalam masalah kinayah Al Mubarrid juga menyinggung pembahasan terkait hal ini didalam al-Kāmil fi al-Lughah wa al-Adab, Dia berkata:"Bahwa sebuah perkataan yang keluar dari lisan seseorang (manusia) itu bermacam-macam bentuknya, diantaranya ada yang memang menunjukkan makna aslinya, ada pula yang dia ucapkan dalam bentuk 
kinayah dari perkataan lainnya, dan ada juga yang sudah menjadi sebuah ungkapan yang baku, dimana ketika itu perkataan tersebut sudah lebih dari sekedar mensifati.

Al-Mubarrid melakukan sistematisasi mengenai konsep kinayah. Dalam karyanya alKamil fi al-Lughah wa al-Adab, al-Mubarrid menguraikan tiga model kinayah yaitu:

a. Menjadikan sesuatu lebih umum

b. Memperindah ungkapan

c. Untaian/ungkapan pujian

Namun Al Mubarrid tidak banyak mengulas pada model pertama dan ketiga, ia lebih menitikberatkan pada model yang kedua, yaitu kinayah sebagai penyempurna keindahan ungkapan, khususnya yang diambil dari ayat-ayat al-Qurān. Kinayah adalah mengungkapan kata, tetapi yang dimaksud bukan makna dari kata itu, sekalipun bisa dibenarkan kalau dipahami sesuai dengan makna dasarnya. Misalnya dalam pribahasa Arab:

$$
\text { اليذّ الطويلة }
$$

\section{Tangan panjang}

Di kalangan orang Arab sangat popular istilah "al-Yad al-Thawilah" untuk menyebut (sebagai kinayah) kepada seseorang yang suka memberi atau membantu. Tetapi kalau "alyad al-thawilah" dipahami sebagai tangan yang panjang, sesuai dengan makna dasarnya juga tidak salah, inilah kinayah. Perhatikan pula dalam surat al-Zukhruf ayat 18:

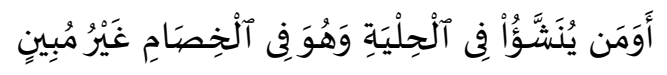

"dan Apakah patut (menjadi anak Allah) orang yang dibesarkan dalam Keadaan berperhiasan sedang Dia tidak dapat memberi alasan yang terang dalam pertengkaran."

Al-Mubarrid menambahkan bahwa sebuah perkataan yang diucapkan dalam bentuk kinayah ada 3 macam sebab, yaitu: Pertama, untuk menutupi atau menyembunyikan. Sebagaimana perkataan An-Nabighah Al-Ja'diy (al-Mubarrid, 1997):

$$
\text { أكني بغير اسمها وقد عد \# اسم الله خفيات كل مكتتم }
$$

Kedua, menghindari daripada ungkapan yang tidak pantas diucapkan. Dan macam yang kedua ini merupakan salah satu pengertian dari kinayah.Mengomentari sebab kinayah yang kedua ini Al-Mubarrid berkata "bahwa kinayah dengan sebab ingin menghindari pengucapan sebuat lafadz yang tidak pantas, kepada lafadz lainnya yang juga menunjukkan maknanya, merupakan sebaik-baik bentuk kinayah" (al-Mubarrid, 1997). Sebagaimana di dalam Al-Qur'an disebutkan bentuk kinayah dari kata Jima' Allah Swt berfirman:

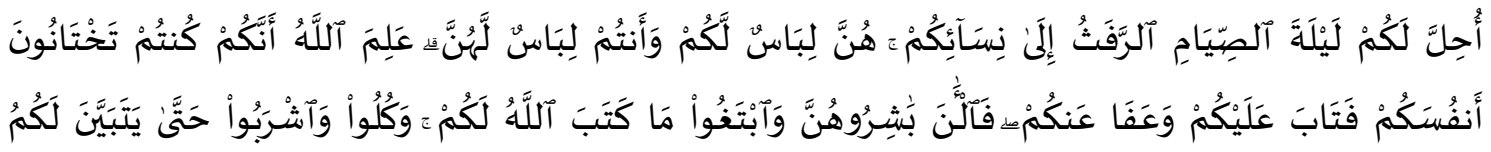




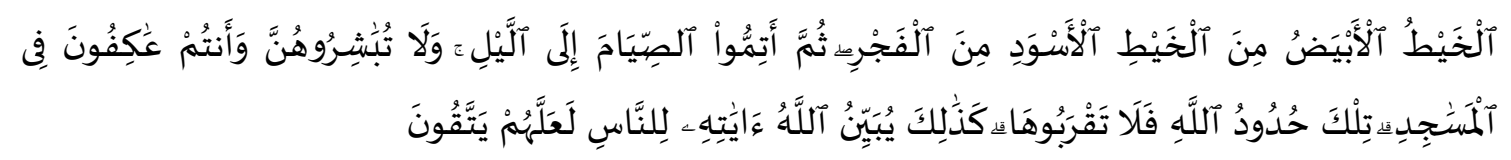

"Dihalalkan bagi kamu pada malam hari bulan puasa bercampur dengan isteri-isteri kamu; mereka adalah pakaian bagimu, dan kamupun adalah pakaian bagi mereka. Allah mengetahui bahwasanya kamu tidak dapat menahan nafsumu, karena itu Allah mengampuni kamu dan memberi ma'af kepadamu. Maka sekarang campurilah mereka dan ikutilah apa yang telah ditetapkan Allah untukmu, dan Makan minumlah hingga terang bagimu benang putih dari benang hitam, Yaitu fajar. kemudian sempurnakanlah puasa itu sampai (datang) malam, (tetapi) janganlah kamu campuri mereka itu, sedang kamu beri'tikaf dalam mesjid. Itulah larangan Allah, Maka janganlah kamu mendekatinya. Demikianlah Allah menerangkan ayat-ayat-Nya kepada manusia, supaya mereka bertakwa."

Dalam ayat diatas, terdapat kalimat Ar Rafatsdan merupakan kinayah daripada kalimat Al Jima'.Mayoritas ulama Fiqh mengatakan bahwa kalimat Laa Mastumdi ayat(أولامستمالنساء)merupakan kinayah dari kata Jima'. Kemudian Al Mubarrid sendiri memisalkan contoh lain dari kinayah dengan Firman Allah Swt yang bercerita tentang AlMasih Isa ibn Maryam dan ibunya (Qs. Al-Maidah [5]: 75).

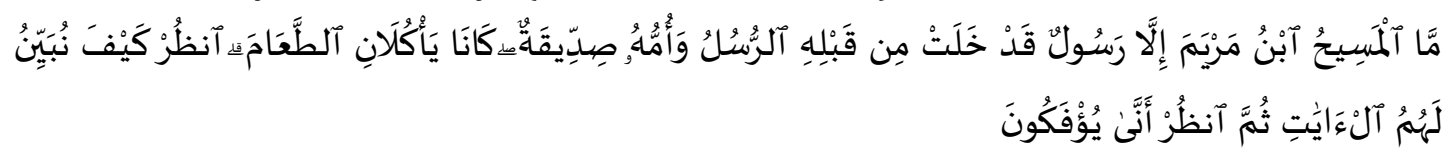

"Al masih putera Maryam itu hanyalah seorang Rasul yang Sesungguhnya telah berlalu sebelumnya beberapa rasul, dan ibunya seorang yang sangat benar, Kedua-duanya biasa memakan makanan. perhatikan bagaimana Kami menjelaskan kepada mereka (ahli Kitab) tanda-tanda kekuasaan (Kami), kemudian perhatikanlah bagaimana mereka berpaling (dari memperhatikan ayat-ayat Kami itu)."

Al-Mubarrid menafsirkan bahwa maksud daripada penggalan ayat diatas adalah mereka berdua juga membuang kotoran mereka, sebagaimana manusia lainnya. Dimana kata Al Aklu (Makan) di ayat tersebut merupakan kinayah dari kata Qadhaul hajah yang artinya membuang kotoran.

Dalam contoh lain Al-Mubarrid juga menafsirkan firman Allāh Swt (Qs. Fushilat [41]: 21):

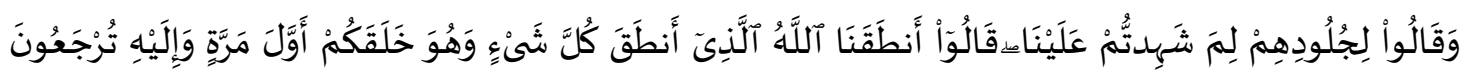

"dan mereka berkata kepada kulit mereka: "Mengapa kamu menjadi saksi terhadap kami?" kulit mereka menjawab: "Allah yang menjadikan segala sesuatu pandai berkata telah menjadikan Kami pandai (pula) berkata, dan Dia-lah yang menciptakan kamu pada kali pertama dan hanya kepada-Nya lah kamu dikembalikan."

Dengan mengatkan bahwa kalimat Al Juludyang artinya kulit tubuh merupakan kinayah daripada kalimat $A l$ furuj yang artinya alat kemaluan. 
Ketiga, memuliakan atau mengagungkan, Al Mubarrid berkata "dari macam ketiga ini muncul salah satu turunan kata yaitu Al Kunyah, yaitu keadaan dimana seorang lakilaki akan bangga jika dipanggil dengan namanya sendiriada 2 macam bentuk Al kunyah yang bisa didapati dalam sebuah perkataan, yaitu:Pertamakunyah pada anak kecil dengan maksud mendo'akan seperti misalnya seseorang yang memiliki anak kemudian seseorang tadi dipanggil dengan nama anaknya tidak dengan namanya dengan maksud kinayah. KeduaAl-Kunyah pada laki-laki dewasa, seperti misalnya seseorang dipanggil dengan nama anaknya tidak dengan namanya dengan maksud menjaga namanya. Dan dikatakan bahwa sesuatu dikinayahkan dengan sesuatu yang lain dengan sebagian sebab yang sudah kami sebutkan (al-Mubarrid, 1997).

Selain contoh-contoh dari al-Qurān Al Mubarrid juga banyak menyebutkan contoh dari Syi'ir sebagai contoh untuk kinayah di beberapa tempat di dalam kitabnya al-Kāmil fi al-Lughah wa al-Adab, diantaranya perkataan Umar bin Abdillah bin Abu Rabi'ah:

$$
\text { طالما عرستم فاستقلوا \# حان من نجم الثرايا طلوع }
$$

Al-Mubarrid berkata seraya mengomentari Syi'ir ini bahwa perkataannya "Haana min Najmits Tsurāya Thuluu'u" merupakan kinayah, dikarenakan yang dimaksud dengan kalimat Tsurāya di Syi'ir adalah anak perempuan dari Ali bin Abdillah bin Al Harts bin Umayyah Al Ashghar (al-Mubarrid, 1997).

Selain macam-macam kinayah yang sudah disebutkan diatas, semuanya bisa kita temukan dalam kitabnya al-Kāmil fi al-Lughah wa al-Adab. Al-Mubarrid menyebutkan Lafadz yang mengadung unsur kinayah beserta arti dan maksudnya diberbagai tempat didalam kitabnya al-Kāmil fi al-Lughah wa al-Adab. Semua yang ia sebutkan terfokus kepada apa yang ia dapatkan daripada perkataan lisan Orang Arab itu sendiri, yang terkadang mereka mengkinayahkan seorang perempuan dengan seekor Sapi dan kambing betina (al-Mubarrid, 1997). Kesimpulannya adalah bahwa Kinayah yang disebutkan oleh Al Mubarrid didalam kitabnya al-Kāmil fi al-Lughah wa al-Adabtidak banyak perbedaan dari apa yang telah disebutkan oleh para pendahulunya dari kalangan Ahli bahasa dan Balāghah baik dari segi bahasanya ataupun pengertiannya. Akan tetapi Al Mubarrid tidak sampai mengumpulkan masalah-masalah terkait kinayah di dalam satu bab khusus di kitabnya al-Kāmil fi al-Lughah wa al-Adab.

\section{$\operatorname{Majaz}(ا ل م ج ا ز)$}

Menurut ulama Balaghah, kata majaz, secara bahasa (etimologi) terbentuk dari kata jaza, yang mengandung makna "melewati tempat tertentu". secara istilah, bisa dilihat dari pernyataan berikut:

$$
\text { اللفظ المستعمل في غيرما وضع له لعلاقة مع قرينة دالة على عدم ارادة المعنى الاصلى }
$$

"lafal (kata) yang digunakan, bukan pada tempatnya, karena adanya hubungan dengan petunjuk yang menunjukkan, bukan pada makna aslinya”. Definisi ini masih sangat umum, karena tidak ada batasan-batasan tertentu yang menjelaskannya secara detil. Tetapi para ahli ushul berpendapat, bahwa majas adalah penggunaan kata yang sulit 
dipahami oleh para pendengarnya. Sebagian lagi mengatakan, bahwa majas adalah mensifati sesuatu dengan sesuatu yang bukan aslinya (Ishaq, $\mathrm{tt}$ ).

Majaz dalam hal ini dibagi dalam dua bagian, yaitu:

Majaz Aqli (مجازعقلي)

Al Mubarrid menyebutkan pembahasan Majaz ini di berbagai tempat secara terpisah dalam kitabnya al-Kamil fi al-Lughah wa al-Adab, dikarenakan beliau tidak sampai mengumpulkannya dalam satu bab khusus. Beliau sendiri pada awalnya tidak memaksudkan penyebutannya dan tidak menyebutkan Majaz dengan nama biasanya. Melainkan ia hanya menyebutkannya secara kebetulan dan dengan maksud meragamkan pembahasan suatu hadits, sebagaimana hal itu merupakan kebiasaan daripada ulama terdahulu semisal Al Jahizh dan Ibnu Qutaibah (al-Mubarrid, 1997). diantara contohcontoh Majaz Aqliy di kitabnya al-Kāmil fi al-Lughah wa al-Adab, Al Mubarrid menyebutkan Firman Allah Swt (Qs. Saba', 33):

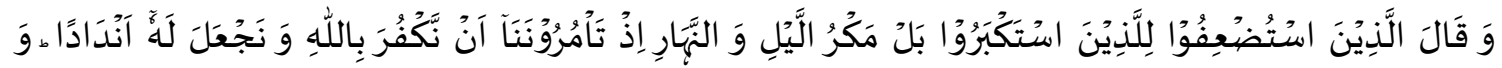

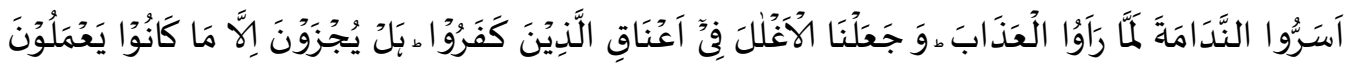

"dan orang-orang yang dianggap lemah berkata kepada orang-orang yang menyombongkan diri: "(Tidak) sebenarnya tipu daya(mu) di waktu malam dan siang (yang menghalangi kami), ketika kamu menyeru Kami supaya Kami kafir kepada Allah dan menjadikan sekutu-sekutu bagi-Nya". kedua belah pihak menyatakan penyesalan tatkala mereka melihat azab. dan Kami pasang belenggu di leher orang-orang yang kafir. mereka tidak dibalas melainkan dengan apa yang telah mereka kerjakan."

Maksud dari "Makrul Lail" adalah Makar mereka (Kuffar) yang dilakukan pada malam hari (al-Mubarrid, 1997). dan Sebuah bait yang dinisbatkan kepada Al Haritsah bin Badr dimana didalamnya ia meratapi kematian Ziyad yang wafat di Kufah dan dimakamkan di Tsaubah, dia berkata (al-Mubarrid, 1997):

$$
\text { صلى الإله على قبروطهره \# عند الثوبة يسقي فوقه المور }
$$

Al Mubarrid berkata seraya mengomentari bait ini, bahwa maksud dari perkataan penyair يسقيفوقهالمورadalah angin yang mengairi debu. Kemudian kata kerja mengairi disandarkan kepada debu setelah dihilangkan kata angin sebelumnya. Sehingga menjadi debu yang mengairi diatasnya. Seperti misalnya kamu mengatakan Allah mengairimu dengan hujan, kemudian boleh bagimu untuk menyandarkan kata kerjamengairi kepada hujan setelah menghilangkan sebelumnya Lafdzul jalalah, kemudian kamu akan mengatakan "Hujan mengairimu wahai pemuda" (al-Mubarrid, 1997).

Dan juga perkataan Yazid bin Hasna' dari kalangan Azariqah (al-Mubarrid, 1997):

$$
\text { فليس بمهد من يكون جاره \# جلادا يمسي ليله غير نائم }
$$


Dimana maksud dari perkatannyaمنيكونهارهجحاداويكسيليلهغيرنائمSeseorang bermalam di rumahnya, akan tetapi kata kerja bermalam disandarkan kepada waktu malam (alMubarrid, 1997).

Dan terakhir perkataan dari Jarir (Hamdani, tt):

$$
\text { لقد لمتنا يا أم غيلان في السرى \# وتمت وما ليل المطى بنائم }
$$

Para Ulama Balāgah setelah Al Mubarrid sama sekali tidak ada menambahkan atas apa yang disebutkan oleh Al Mubarrid di kitabnya. begitupun ulama-ulama sebelumnya dan yang semasa dengannya. Mereka sepakat terhadap makna dan pengertian dari Majaz Aqliy yaitu sebuah uslub dimana kita menyandarkan sebuah kata kerja kepada selain subjek aslinya. Dan Al Mubarrid sendiri banyak menafsirkan Ayat-ayat Al-Qurān dan menjabarkan hadist-hadist sekaligus menjelaskan apa yang didalam setiap ayat dan hadist daripada Uslub Majaz khususnya Majaz Aqliy (Hamdani, tt)

\section{Majaz Lughawy (مجاز لغوي)}

Pengertian Majaz Lughawy menurut istilah adalah:

المجاز اللغوي هو كلمة استعملت في غير ما وضعت له لعلاقة مع قرينة تمنع من إرادة المعنى الحقيقيي

"Majaz Lughawy adalah kata yang digunakan tidak pada tempatnya, karena ada keterkaitan serta alasan yang mencegah dari makna hakiki".

Adapun Pembagian Majaz Lughawy ada 2, yaitu:

\section{Majaz Mursal (مجازمرسل)}

adalah bahasa kiasan sama seperti al-isti'arah (Hamdani, tt) bedanya jika isti'arah memakai hubungan persamaan (علاقة المشابهة), sedangkan Majaz Mursal memakai hubungan bukan persamaan (علاقة غير المشابهة).

Kemudian al-Mubarrid menyebutkan Diantara bentuk-bentuk Majaz mursal yang disebutkannya melalui tafsirannya terkait Firman Allah Swt. yang bercerita tentang Nabi Ibrahim Alaihis sallam (Qs. Al-Syu'araa', 84):

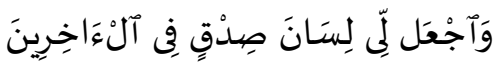

"dan Jadikanlah aku buah tutur yang baik bagi orang-orang (yang datang) Kemudian,"

Al Mubarrid berkata bahwa maksud daripada "lisana Shidqin" adalah sebutan yang baik atau pujian (al-Mubarrid, 1997). Begitu juga bisa kita dapati di tafsirannya terkait firman Allah Swt (Qs. Yusuf, 36):

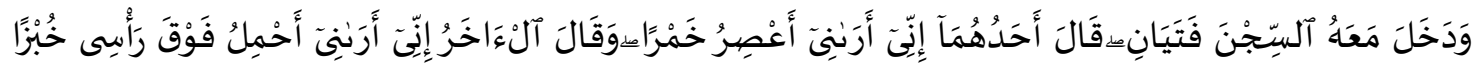

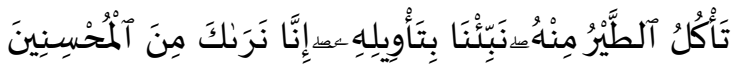

"dan bersama dengan Dia masuk pula ke dalam penjara dua orang pemuda. berkatalah salah seorang diantara keduanya: "Sesungguhnya aku bermimpi, bahwa aku 
memeras anggur." dan yang lainnya berkata: "Sesungguhnya aku bermimpi, bahwa aku membawa roti di atas kepalaku, sebahagiannya dimakan burung." berikanlah kepada Kami ta'birnya; Sesungguhnya Kami memandang kamu Termasuk orang-orang yang pandai (mena'birkan mimpi)".

Al Mubarrid berkata bahwa maksudnya adalah memerah anggur, hingga sampai menjadi Khamar (al-Mubarrid, 1997) yang demikian adalah Majaz mursal dimana hubungan antara kalimat pengganti dengan kalimat yang diganti adalah pertimbangan hasil akhir. Dimana Khamar merupakan hasil daripada anggur.Al Mubarrid juga menyebutkan sebuah Syi'r Arab yang dinisbatkan kepada seorang Rajiz (penyair yang memiliki Syi'ir dalam bahr Rajaz) yang didalamnya mensifati awan mendung:

$$
\text { أفضل في المستن ربليه \# أسنمة الآبال في سحابه }
$$

Didalamnya ia ingin memaksudkan bahwa Langitlah yang menumbuhkan Tumbuhan-tumbuhan yang dimakan Onta sehingga menjadi lemak di tungkuknya. Murshifiy berkata "Perkataan Penyair ( $F a$ tashiiru dan seterusnya) merupakan Majaz Mursal dan hubungan antar kata yang diganti dan yang mengganti adalah seperti yang pertama" (Murshofi, 1970).

Mereka yang benar-benar memperhatikan setiap kata Al Majaz yang terdapat di Al Kamil Al-Mubarrid, bahwa setiap katanya tidak menunjukkan pengertian Majaz yang serupa dengan apa yang didapati di dalam kitab ulama sebelumnya semisal Kitab Ma'anil Qur'an karya Al Farra' dan kitab Majazul Qur'ankaarya Abu Ubaidah dan lainnya. Alasannya adalah karena Majaz yang kita ketahui sekarang belum didapati pada masa sebelum Al Mubarrid. Hal itu dapat dijelaskan dengan perkataan Al Mubarrid " dan kami sebutkan beberapa ayat Al-Quran yang mengandung Uslub Majaz yang masih difahami keliru oleh Para ahli Nahwu" (al-Mubarrid, 1997).

\section{Al-Isti'arah (الإستعارة)}

Menurut Bahasa isti'arah berati "tholabul iarah" (mencari pinjaman), Ibn Qutaibah (w. 276-H), mengatakan bahwa isti'arah adalah peminjaman kata untuk dipakai dalam kata yang lain karena ada beberapa faktor. Pada lazimnya, orang Arab sering meminjam kata dan menempatkannya untuk kata lain tatkala ditemukan alas an-alasan yang membenarkan (Ridwan, 2007).

Terkait pembahasan Isti'arah, Al Mubarrid juga banyak menyebutkan di tafsirannya pada ayat-ayat Al-Qur'an.Diantaranya Seperti Firman Allah Swt (Qs. AtTaubah, 93):

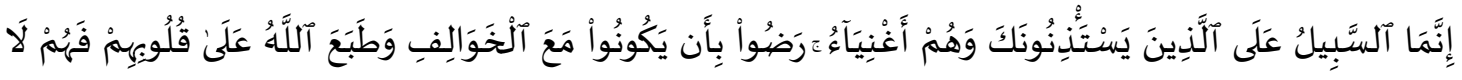

$$
\begin{aligned}
& \text { يَعْلَمُونَ }
\end{aligned}
$$

"Sesungguhnya jalan (untuk menyalahkan) hanyalah terhadap orang-orang yang meminta izin kepadamu, Padahal mereka itu orang-orang kaya. mereka rela berada bersama orangorang yang tidak ikut berperang dan Allah telah mengunci mati hati mereka, Maka mereka tidak mengetahui (akibat perbuatan mereka)". 
Ath thab' merupakan bentuk ketamakan yang paling buruk dan dasarnya setiap hati yang terbiasa akan sesuatu yang jelek sampai-sampai mengendalikannya. Sehingga ia benar-benar seperti penghalang diantara hati dan pemahaman yang benar. Dimana segala apa yang tampak dari hati akan terlihat jelek. Dan Ath Thaba' sudah menjadi sebuah ungkapan baku, asal kata tersebut disandingkan dengan Kata pedang, dikatakan "Thaba's saif" yaitu apabila karat mengendalikannya sehingga menutupi badan besinya. (alMubarrid, 1997).

Al Mubarrid seraya berkata menjelaskan sebuah baik Syi'ir yang dinisbatkan kepada Al Qatahmiy:

$$
\text { نقربهم لهذميات نقد ما \# ما كان حاط عليهم كل زواد }
$$

Al-Mubarrid berkata "Karena jahitan dapat menutupi lubang di pakaian, dan Penambalan menutupi lubang di baju besi. Karena kemudian sudah menjadi sebuah ungkapan baku. Maka ia mengangapnya sebuah jahitan.Al Murshif berkata:"Bahwa huruf ya' di kata Lahdzamiyyat bukanlah ya' nisbah melainkan ya' yang didatangkan untuk menunjukkan makna mubalagah. Dan kata Lahdzam seperti Ja'far yang sama-sama berwazan Fa'lalun. Dan lahdzam bermakna pedang yang tajam dan bisa juga bermakna mata panah. Seorang penikam ulung menjadikannya seperti makanan yang ia suguhkan kepada tamu-tamunya (lawan) (Hamdani, tt).

Al Mubarrid berkata seraya menerangkan serangkain bait Syi'ir seorang pemuda dari Thayyi' yaitu Anif An Nabhaniy:

$$
\text { لهمعنا لعم من حي غوث ومالك \# كتائب يردي المقرفين لمالكها }
$$

Al Muqrifin mereka adalah orang-orang masuk kepada kerusakan (orang-orang yang memuakkan). Dan arti kata $\mathrm{Al} \mathrm{Ajz} \mathrm{di} \mathrm{bait} \mathrm{adalah} \mathrm{bagian} \mathrm{belakang} \mathrm{sebuah} \mathrm{pasukan,}$ dimana ia merupakan kata pinjaman yang aslinya disandarkan kepada manusia dan juga hewan berkaki empat, yang artinya bagian belakang keduanya (Punggung) (Murshofi, 1970).

\section{b. Ilmu Badi' dan ilmu Ma'ani}

Al-Mubarrid juga menyinggung dalam sebagian pembahasannya terkait tentang ilmu Badi' dan ilmu Ma'ani, akan tetapi dalam artikel ini hanya dibahas beberapa bagian.

$$
\text { Al-Qalb (القلب) }
$$

Dalam pembahasan Al-Qalb al-Mubarrid mengambil contoh dari ayat (Qs. AlQashash,76) :

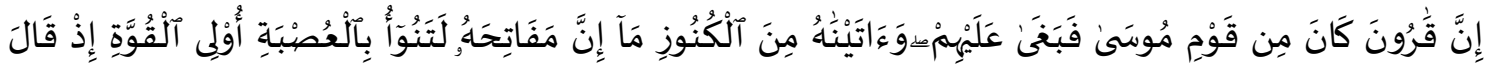

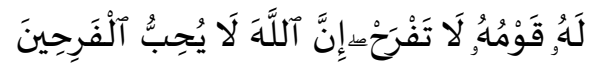

"Sesungguhnya Karun adalah Termasuk kaum Musa, Maka ia Berlaku aniaya terhadap mereka, dan Kami telah menganugerahkan kepadanya perbendaharaan harta yang kuncikuncinya sungguh berat dipikul oleh sejumlah orang yang kuat-kuat. (ingatlah) ketika 
kaumnya berkata kepadanya: "Janganlah kamu terlalu bangga; Sesungguhnya Allah tidak menyukai orang-orang yang terlalu membanggakan diri".

Dan maksud daripada "Al Ushbatu tanuu bil mafaatiih" adalah kelompok yang tidak sanggup membawa kunci-kunci dikarenakan berat. Diantara perkataan orang Arab yang serupa berbunyi "Inna Fulanah la tanu'u" yang artinya lemah dan tidak sanggup membawa muatan.

Dan kemudian Al Mubarrida menyebutkan contoh-contoh bentuk syi'ir lain yang mengandung salah satu muhassinat yaitu Qalb (Murshofi, 1970).

\section{Al Iltifat (التفات)}

Secara bahasa al-Iltifat artinya melirik, mengalihkan. Maksudnya mengalihkan perhatian mukhathab dari satu ke yang lain diantara kata ganti pertama. Gaya bahasa iltifat sering digunakan dalam komunikasi sehari-hari (Hidayat, 2002).

Secara istilah ahli Balaghah sebagaimana yang di kemukakan oleh al-Hāsyimi dalam kitabnya,Iltifat adalah perpindahan dari semua dhamir; mutakallim, mukhatab atau gaib kepada dhamir lain, karena tuntutan dan keserasian yang lahir melalui pertimbangan dalam mengubah perpindahan itu, untuk menghiasi percakapan dan mewarnai seruan, agar pendengar tidak jemu dengan satu keadaan dan sebagai dorongan untuk lebih memperhatikan, karena dalam setiap yang baru itu ada kenyamanan, sedangkan sebagian al-Iltifat memiliki kelembutan, pemiliknya adalah rasa bahasa yang sehat"

Sebagai contoh dari gaya bahasa Iltifat yang ada dalam al-Quran (Qs. Ali Imran, 3),

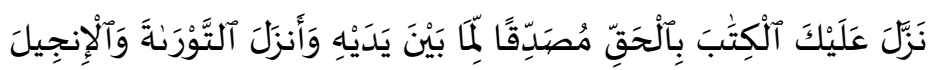

"Dia menurunkan Al kitab (Al Quran) kepadamu dengan sebenarnya; membenarkan kitab yang telah diturunkan sebelumnya dan menurunkan Taurat dan Injil,"Ayat tersebut terdapat gaya bahasa al-iltifat pada pemilihan kata نَزَّ yang berarti menurunkan, kepada pemilihan kata أَنَّل yang berarti Dia (Allah) menurunkan.

Sementara Al Mubarrid dalam memberikan contoh terkait gaya bahasa iltifat beliau mengambil contoh dari Syi'ir Al A'sya yang berbunyi:

$$
\text { وأمتعني على العشا بوليدة \# فأبت بخير منك يا هوذ حامدا }
$$

Al Mubarrid berkata mengomentari Syi'ir ini, bahwa Al A'sya didalam Syi'irnya berbicara mengenai seseorang kemudian dia sendiri berbicara dengan orang tersebut dan seterusnya meninggalkan percakapan dengan orang tersebut. Memang biasanya orang Arab meninggalkan percakapan terkait orang yang jauh kepada percakapan terkait orang yang dekat, dan sebaliknya. Selain mengambil dari syi'ir al-mubarrid juga mengambil contoh dari ayat al-Quran (Qs. Yunus, 22),

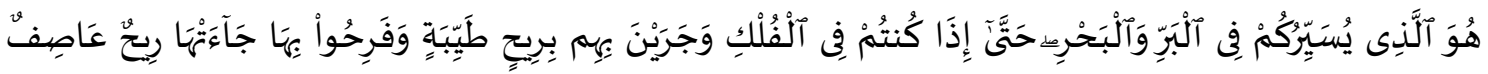

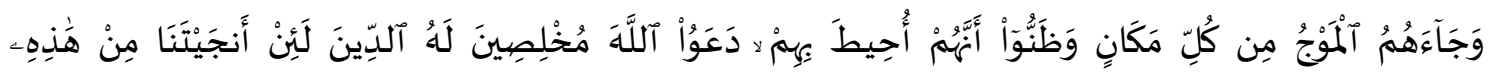

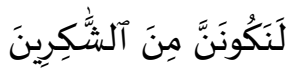


"Dialah Tuhan yang menjadikan kamu dapat berjalan di daratan, (berlayar) di lautan. sehingga apabila kamu berada di dalam bahtera, dan meluncurlah bahtera itu membawa orang-orang yang ada di dalamnya dengan tiupan angin yang baik, dan mereka bergembira karenanya, datanglah angin badai, dan (apabila) gelombang dari segenap penjuru menimpanya, dan mereka yakin bahwa mereka telah terkepung (bahaya), Maka mereka berdoa kepada Allah dengan mengikhlaskan ketaatan kepada-Nya semata-mata. (mereka berkata): "Sesungguhnya jika Engkau menyelamatkan Kami dari bahaya ini, pastilah Kami akan Termasuk orang-orang yang bersyukur."

Percakapan awalnya terkait suatu kaum kemudian berpindah kepada pengabaran kepada Nabi Saw terkait keadaan kaum tersebut.Dan masih banyak lagi contoh yang lain (Murshofi, 1970).

\section{Al Laf wan Nasyr (اللف والنشر)}

Secara etimologi النشر artinya menyebarkan atau membentangkan. Maksudnya adalah melipat (menghimpun) dua hal atau lebih, kemudian disusul (dibentangkan) oleh katerangan masing-masing secara berurutan.

Menurut istilah ahli balaghah اللف gdalah

(http://nenenggeulis.blogspot.com/):

$$
\begin{aligned}
& \text { أن يذكر متعددة ثمّ يذكر ما لكل من افراده شائعا من غير تعيين اعتماداعلى تصريف السامع في تمييز ما لكل :(لما/مل } \\
& \text { واحد منها ورده إلى ما هوله. }
\end{aligned}
$$

"Al laf wa Nasyru adalah menyebutkan beberapa makna kemudian menentukan makna untuk masing-masing satuanya secara umum dengan tanpa menentukan, karena bersandar kepada upaya pendengar dalam membedakan makna untuk masing-masing dari padanya dan mengembalikan untukyang semestinya."

Gaya bahasa ini diperoleh dari apa yang dinukilkan dari Ubaidillah bin Abdillah bin Utbah bahw aia berkata" sebai-baiknya kebaikan ialah yang memiliki pengaruh kepada keburukan dan seburuk-buruknya keburukan adalah yang memiliki pengaruh kepada kebaikan. Orang Arab sejatinya sering mencampurkan dua keterangan yang berbeda dimana kemudian mendatangkan tafsiran dari keduanya dalam bentuk yang membuat si pendengar mengembalikannya kepada setiap keterangan yang ada. Allah Swt berfirman (Qs. Al-Qashash , 73):

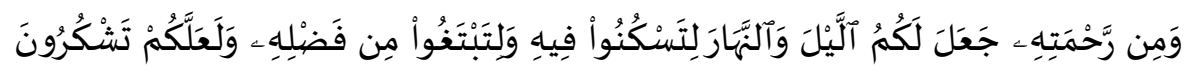

"dan karena rahmat-Nya, Dia jadikan untukmu malam dan siang, supaya kamu beristirahat pada malam itu dan supaya kamu mencari sebahagian dari karunia-Nya (pada siang hari) dan agar kamu bersyukur kepada-Nya."

Dengan mengetahui bahwa si pendengar atau lawan bicara sebelumnya sudah menngetahui kapan waktu untuk beristirahat dan kapan waktu untuk beraktivitas.Al 
Murshifi berkata mengomentari perkataan Al Mubarrid, bahwa yang dimaksud dari perkataan beliau "orang Arab sering mencampurkan (Al Laffu) dan seterusnya." Adalah Al Laffu wan nasyr Al Murattab. Yaitu pencampuran dua keterangan dengan mendatangkan tafsiran dari keduanya secara berurutan (Hamdani, $\mathrm{tt}$ ).

\section{Al Istifham (إمتفهام)}

Al Mubarrid juga menyebutkan beberapa shigah (bentuk) yang terkadang disisipi kepada khabar seperti shigah Istifham. Sebagaimana Istifham bisa temukandalam perkataan Abdullah bin Muawiyah:

$$
\text { أنت أخي ما لم تكن لي حاجة \# فإن عرضت أيقنت أن لا أخاليا }
$$

Al Mubarrid berkata "bahwa syi'ir diatas termasuk sebuah taqrir (keterangan) dan bukanlah sebuah istifham (pertanyaan). Dimana maksud dari syi'ir adalah ketika aku mengujimu dan kamu dalam kesulitan senantiasa kamu menunjukkan persaudaraan, namun ketika sebaliknya, aku memiliki kebutuhan mendadak, aku tidak mendapati sama sekali bentuk persaudaraan dan rangkulan darimu.

Allāh Swt berfirman (Qs. Al-Māidah, 116):

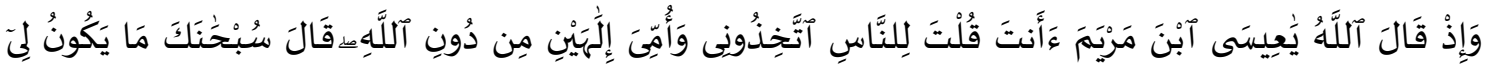

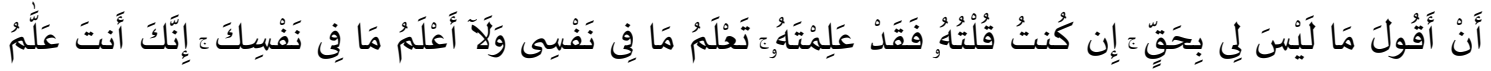

"dan (ingatlah) ketika Allah berfirman: "Hai Isa putera Maryam, Adakah kamu mengatakan kepada manusia: "Jadikanlah aku dan ibuku dua orang Tuhan selain Allah?". Isa menjawab: "Maha suci Engkau, tidaklah patut bagiku mengatakan apa yang bukan hakku (mengatakannya). jika aku pernah mengatakan Maka tentulah Engkau mengetahui apa yang ada pada diriku dan aku tidak mengetahui apa yang ada pada diri Engkau. Sesungguhnya Engkau Maha mengetahui perkara yang ghaib-ghaib".

Al Mubarrid menjelaskan maksud daripada shigah yang terkandung di dalam ayat diatas, ia berkata Bahwa itu adalah shigah At-Taubikh (celaan) terhadap kaum nabi isa dan bukankah shigah istifham, karena Allāh Swt pada asalnya mengetahui bahwa Nabi isa tidak akan mengatkan hal demikian.

\section{Pengaruh Al Mubarrid Bagi Ulama Balāghah Setelahnya}

Tidak ada sebuah ilmu baik yang bersifat teoritis ataupun praktek yang diawal kemunculannya langsung sempurna dalam satu masa.Tentunya semua itu akan mengalami fase sejarah dimana ia muncul, berkembang, dan maju, hingga bisajadi mengalami kepunahan. Karena pada intinya setiap cabang ilmu pengetahuan pasti akan selalu tumbuh dan berkembang. Pada awalnya hanya berupa pondasi dan rumus-rumus dasar yang sedikit, kemudian yang sedikit itu akan menjadi banyak dan terus berkembang disebabkan oleh usaha dan upaya dari mereka yang mempelajari ilmu tersebut serta mengajarkannya. Demikianlah peran Al Mubarrid dalam meletakkan rumus-rumus dasar yang kemudian dimanfaatkan oleh ulama-ulama setelahnya dan sekaligus membantu 
mereka dalam membangun sebuah cabang ilmu yang berdiri sendiri khususnya terkait pembahasan at-tasybih beserta macamnya dan juga terkait jawaban alMubarrid terhadap pertanyan dari Al Kindi dimana hal itu telah membuka sebuah pintu yang sangat luas bagi ulama-ulama Nahwu dan Balāgah setelahnya. Kemudian mereka berusaha mempelajarinya hingga sampailah mereka kepada peletakan sebuah pembahasa khusus terkait Adrabul khabar (Macam-macam khabar). Diantara ulama-ulama belakangan (Mutaakhkhirin) yang menonjol, dan mengambil secara langsung sanad keilmuan dari Al Mubarrid seperti IbnuMu'taz, Qudamah, Abdul Qahir Al-Jurjani, dan Al khatib Al Quzwini (Hamdani, $\mathrm{tt}$ ).

Adapun Ibnu Mu'taz, beliau telah berguru kepada Al Mubarrid dalam Adab dan Ilmu Bahasa Arab, sebagaiman ia juga berguru kepada guru lain semisal Abul Abbas Tsa'lab. Diketahui bahwa telah terjadi banyak diskusi dan perdebatan antara Al Mubarrid dengan muridnya IbnuMu'taz dalam Adab (sastra), Syi'ir dan Naqd. Adapun pengaruh Al Mubarrid dalam keilmuan IbnuMu'taz hal itu dapat diketahui dan dilihat dari penggunaan IbnuMu'taz beberapa Istilah yang biasa disebutkan Al Mubarrid dalam masalah at-tasybih di dalam kitabnya $\mathrm{Al} \mathrm{Badi',} \mathrm{beliau} \mathrm{di} \mathrm{dalam} \mathrm{kitabnya} \mathrm{"Diantara} \mathrm{tasybih} \mathrm{ada} \mathrm{yang} \mathrm{disebut}$ dengan Al Hasan atau termasuk tasybih terbaik dan at-tasybih Al Ajib"(Mu'taz, 2012).

Begitupun dengan Qudamah bin Ja'far dia juga mengambil manfaat dari apa yang telah disebutkan oleh pendahulunya semisal Al Mubarrid dan Ibnu Thabā Thabā ketika beliau berbicara mengenai makna daripada tasybih. Kendati beliau tetap berusaha menjaga kepribadiannya dan juga kebebasan berfikirnya dalam memilih gaya bahasa yang sesuai dengan pandangnnya, begitu juga dalam meimilih bukti-bukti Syi'ir dan juga pembicaraan terkait cara para pujangga dalam berinteraksi dengan tasybih di dalam syi'ir mereka.

Qudamah berkata "Sesungguhnya diantara hal-hal yang sudah diketahui secara gamblang bahwa sesuatu itu tidak diserupakan dengan dirinya sendiri ataupun dengan lainnya dari setiap sisi. Dikarenakan jika ada dua hal yang diserupakan atau memiliki keserupaan dari setiap sisinya tanpa memiliki perbedaan sama sekali, maka itu bukan lagi tasyabuh melainkan Ittihad(kesatuan), dimana dua hal tersebut pada haqiqatnya sama dan satu. Adapun yang disebut dengan tasybih yaitu jika ada dua hal yang memiliki keserupaan dalam beberapa sifat, yang keduanya sama-sama bersifat dengannya dan juga perbedaan dalam beberapa hal yang dimiliki oleh masing-masing dari keduanya.Jika demikian perkaranya maka dapat disimpulkan bahwa tasybih yang baik adalah Penyerupaan yang terjadi pada dua hal, dimana keserupaan keduanya dalam Sifat-sifatnya lebih banyak daripada perbedaanya, sehingga mendekati kepada keadaan Ittihad (kesatuan).Catatan dari Qudamah ini mengandung dua konsep penting, yaitu:pertama adalah bahwa dua hal yang diserupakan mesti memiliki kesamaan dalam beberapa sifatnya saja dan memiliki perbedaan di Sifatnya yang lain. Dan konsep ini adalah apa yang terkandung di dalam perkataan Al Mubarrid. Kedua, bahwa semakin banyak kesamaan antar dua hal tadi, maka semakin baiklah bentuk perumpamaannya. Dan konsep ini juga tampak jelas pada sebuah ungkapan ibnu Thabathaba.Bahwa semuanya didapati tidak 
serta merta dari usaha besar Qudamah sendiri, melainkan ada yang mendahuluinya dan ini berlaku dikebanyakan pembahasan Balagah.

Sebagaimana kita akan jelas mengenai pengaruh Al Mubarrid terhadap keilmuan Qudamah ketika ia berbicara mengenai tasybih di dalam kitabnya "Naqdun Natsr",ia secara gamblang menetapkan satu bab khusus yang berbicara mengenai tasybih, kemudian didalamnya ia mengartikan tasybih dengan pengertian yang akan menarik kembali memori kita kepada pengertian tasybih yang disebutkan oleh Al Mubarrid dalam kitab alKāmil fi al-Lughah wa al-Adab. Qudamah berkata" Adapun tasybih, ia merupakan satu dari sekian banyak kemuliaan dalam bahasa Arab, didalamnya terdapat kecerdasan dan keterampilan mereka (Orang Arab). Semakin lembut seorang pujangga (musyabbih) maka semakin taulah ia akan syi'ir. Dan semakin awal seseorang memahami sesuatu maka semakin cakaplah ia.

Qudamah ibnu Ja'far membagi tasybih kepada dua bentuk Umum : Dhzahiriy, dan Ma'nawiy, yang dimaksud dengan tasybih Dzahihiry ialah tasybih asli menurut Al Mubarrid. Dan kitaakan temukan bahwa dalil Syi'ir terkait tasybih Dzahiriy, ia juga dalil bagi Tasybih Asli menurut Al Mubarrid. Adapun untuk bentuk kedua, yang pada aslinya merupakan Tasybih Ajib menurut Al Mubarrid, maka Qudamah sendiri menyisipi pembahasannya pada sebuah bait Syi'ir seorang Pujangga An Nabigah Adz Dzaibaniy, yang berbunyi:

$$
\text { فإنك كالليل الذي هو مدركي \# وإن خلت أن المتأى عنك واسع }
$$

Adapun ulama lainnya seperti Abdul Qahir Al-Jurjani. Al-Jurjani sendiri banyak terpengaruh oleh pernyataan dan pemikiran pemikiran Al Mubarrid, ia banyak menelaah serta memikirkannya hingga ia bisa membuka pintu-pintu ilmu baru bagi ulama Balāghah setelahnya, dimana dengannya mereka dapat menyelesaikan sebuah fashl yang berbicara khusus mengenai macam-macam daripada Isnad Khabariy. Keterangan Al Mubarrid yang paling penting, yang menjadi perhatian daripada Abdul Qahir Al-Jurjaniy adalah jawaban Al Mubarrid terkait Pertanyaan dari seorang Al Kindiy.

Abdul Qahir berusaha mencermati jawaban tersebut dan mencoba membangun sesuatu dari konsep Al Mubarrid yang berbunyi "Bahwa perbedaan Makna dalam sebuah kalam disebabkan oleh perbedaan lafadz-lafadznya". ia Mencoba memahaminya lebih dalam dan mengeluarkan kesimpulan-kesimpulan darinya hingga sampai mempelajari hubungan antara sebuah lafadz dengan makna.Pengaruh Al Mubarrid terhadapa keilmuan Abdul Qahir Al-Jurjanijuga tampak, ketika beliau berbicara mengenain tasybih, Al-Jurjani banyak menyebutkan Bait-biar Syi'ir yang sejatinya disebutkan juga Al Mubarrid.

Al Khatib Al Qazwaini termasuk diatara ulama Balāghah yang mengambil manfaat daripada penguraian Abdul Qahir Al Jurjaniy atas Jawaban Al Mubarrid. Al Khatib meletakkan satu Fashl khusus terkait "Keadaan-keadaan Isnad khabari" di dalam kitabnya "Al Idhah fii ulūmil Balāghah". Ia memulai dengan berbicara terkait apa itu Faidatul Khabar dan apa itu Lazim faidatil khabar, hingga berpindah kepada pembahasan Macammacam khabar. Kemudian Qazwainiy memberikan nama-nama bagi setiap macam khabar, ia menamai macam pertama dengan ibtida'iy, dan yang kedua dengan Thalabiy, dan yang 
ketiga dengan Inkariy. Sebagaimana Al Khatib Al Qazwainiy juga mengkhususkan satuFashl yang berbicara mengenai tasybih, ia didalamnya banyak menyebutkan Bait-bait Syi'ir yang juga disebutkan Al Mubarrid dalam kitabnya al-Kämil fi al-Lughah wa al-Adab.

\section{Kesimpulan}

Dari paparan diatas dapat diambil kesimpulan, bahwa pemikiran-pemikiran AlMubarrid terkait Ilmu Balagah setidaknya telahmempengaruhi ulama-ulamasetelahnya, sebagaimana ia berpengaruh dalam berbagai Bahasan Balāghah dan bahasa. Terutama melalui Karya monumentalnya terhadap sastra dan budaya, al-Mubarrid mewariskan karya yaitu al-Kamil fi al-Lughah wa al-Adab. Sesuai dengan judulnya, buku ini memuat kapita selekta tentang linguistik, kebudayaan Islam, sastra, sejarah, dan gramatika. Sastra Arab yang dimuat dalam buku ini tidak hanya berupa prosa dan puisi, melainkan juga pribahasa, kata-kata mutiara, syair-syair (puisi-puisi) dan khutbah-khutbah berbobot (bermutu). Pemikiran otentik linguistik al-Mubarrid dapat direkonstruksi dan dikritisi melalui buku momentalnya tersebut.

Akhir kata Tentu saja artikel ini hanya sebatas pengenalan awal, dan masih banyak kekurangan serta masih harus melakukan penelitian lanjutan untuk mengetahui dan mengungkap kontribusi al-Mubarrid dalam kajian ilmu balāghah. 


\section{Daftar Pustaka}

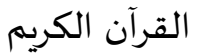

$$
\begin{aligned}
& \text { رمضيان عبد التواب، البلاغة لأبي العباس محمّلد بن يزيد المبرّد، القاهرة: مكتبة الثاقفة الدينية، } 1910
\end{aligned}
$$

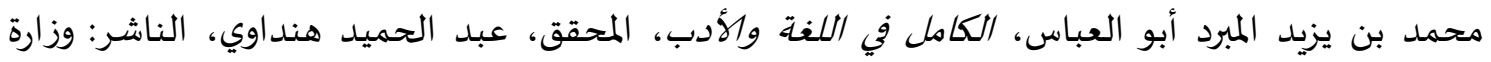

$$
\begin{aligned}
& \text { الأوقاف السعودية، سنة النشر: 1991 } \\
& \text { أبو العباس محمد بن يزيد المبرد،/لمقتضب، المحقق: محمد عبد الخالق عضيمة، القاهرة: وزارة الأوقاف - }
\end{aligned}
$$

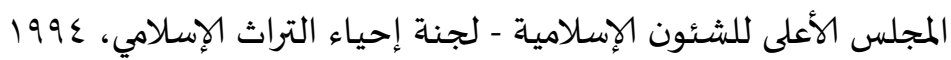

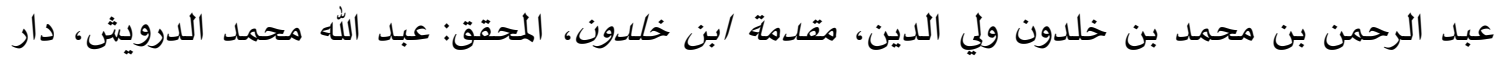

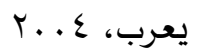

$$
\begin{aligned}
& \text { الخطيب القزويني محمد بن عبد الرحمن جلال الدين، الإيضاح في علوم البلاغة المعاني والبيان والبلديع، }
\end{aligned}
$$

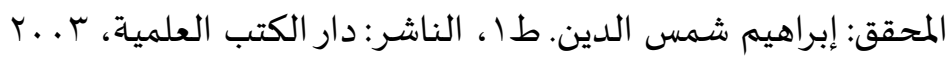

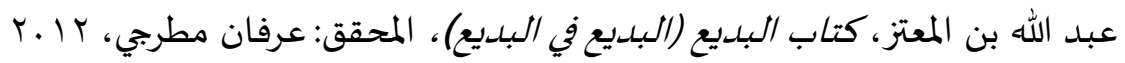

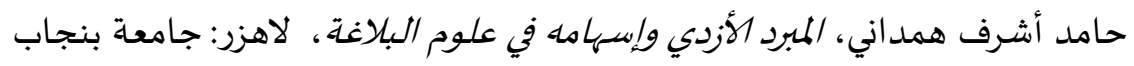

$$
\begin{aligned}
& \text { المرصفى، رغبة الآمل من كتاب الكمل، مكتبة الاسدى ، . 19V }
\end{aligned}
$$

Abbas Sofwan, Abrogasi Al-Quran dan Sunnah Menurut Ibnu Qutaibah dalam Ta'wîl Mukhtalaf Hadîts, Al-Tsaqafah, Vol. 14, No. 1, Mei 2018, h. 94

Ach. Thabrani, Nadzam Dalam I'jaz Al Quran Menurut Abdul Qahir Al Jurjani, Jurnal Al Mi'yar Vol. 1, No. 1 April 2018

Ade Nurdiyanto, Istifham Dalam Al-Qur'an: Studi Analisa Balaghah, El-Wasathiya: Jurnal

Studi Agama, Volume 4, Nomor 1, Juni 2016

D. Hidayat, Al-Balaghah lil Jami', Semarang: PT Karya Toha Putra, 2002

Moh. Muhtador Nawafi, Eksistensi Majas Dalam Alqur'an Sebagai Khazanah Keilmuan Islam, Al-'Araf Jurnal Pemikiran Islam dan Filsafat- Vol. XIV, No. 2, Juli - Desember 2017

Mubaidillah, Memahami Isti'arah Dalam Al-Quran, Nur El-Islam,Volume 4, Nomor 2, Oktober 2017

Muhbib Abdul Wahab, Mengenal Pemikiran Linguistik Al-Mubarrid (210 - 285 H/826 - 898

M), online, https://fitk.uinjkt.ac.id/mengenal-pemikiran-linguistik-al-mubarrid-210285-h826-898-m/, diakses 17 Mei 2019

Ridwan, Peminjaman Kata (Isti'arah) Dalam Al-Qur'an (Kajian Susastra Dalam AL-Quran), Jurnal "el-Harakah" Vol. 9, No. 3 September-Desember 2007

Sopwan Mulyawan, Studi Ilmu Ma'ani (Stylistic) Terhadap Ayat-Ayat Surat Yasin, Holistik

Vol 12 Nomor 02, Desember 2011/1433 H

http://nenenggeulis.blogspot.com/2015/05/blog-post.html, diakses 20 Agustus 2019 